https://doi.org/10.31470/2706-7904-2021-16-283-288

\title{
LANGUAGE DEVELOPMENT AT EARLY CHILDHOOD: AN OVERVIEW IN THE CONTEXT OF PSYCHOLINGUISTICS
}

\author{
Розвиток мовлення в ранньому дитинстві: огляд у контексті \\ психолінгвістики
}

\author{
Kasım Tatlııı̆glu \\ Ph.D. in Psychology, Associate Professor \\ Bingol University (Turkey) \\ kasimtatlili@ hotmail.com \\ https://orcid.org/0000-0001-5964-4343 \\ Nadiia Senchylo-Tatlilioğlu \\ Ph.D. in Philology, Associate Professor \\ National Aviation University (Ukraine) \\ ifyc22@ukr.net \\ https://orcid.org/0000-0001-9196-7118
}

\begin{abstract}
Language acquisition is the process during which humans acquire the capacity to see, create and utilize words to get it and communicate. It includes the picking up of differing capacities involving language structure, phonetics, and a broad lexicon. Language development is thought to proceed by ordinary processes of learning in which children acquire the forms, meanings, and uses of words and utterances from the linguistic input. Language ability is an indispensable place among human intellectual abilities and language is considered to be the most important component of the human mind language development starts from the first cry until a child is able to speak a word. It includes the picking up of differing capacities involving language structure, phonetics, and a broad lexicon. Talking is like an action and it is shaped by motives of many kinds. As an interdisciplinary field, psycholinguistics in the world revealed at the intersection of psychology and linguistics in the 1950s. It is seen that studies on language development have increased in recent years. This study is describe how language developed at the early childhood.
\end{abstract}

Key words: psycholinguistics, psycholinguistic development, pre-education period, acquisition process, early childhood.

\section{Introduction Bcmyn}

Language is a very important element that all living beings use to communicate. Unlike other beings, the language that people use has a complex system. From the past to 
the present day, a variety of theories have been found in terms of language formation and development, and children are tried to be educated through programs created on the basis of these theories for their language development (Çelik, 2017: 193). Language development starts from birth and continues throughout life (Tatlılığlu \& Senchylo-Tatlılığlu, 2020: 245). Even though children who are exposed to a language at a very early age, it differs in production, because children acquire language in some stages and some of the children get various stages at different times (Ateş, 2019: 34).

Psycholinguistics or psychology of language is the study of the interrelation between linguistic factors and psychological aspects. The discipline is mainly concerned with the mechanisms by which language is processed and represented in the mind and brain. Psycholinguistics contains data that enable not only individuals to express themselves in an elegant and effective way, but also communities to establish a healthy communication (Taştekin, 2016: 987). There is still no theory that can fully explain how language is acquired.

\section{Methods and Techniques of the Research Методи і методики дослідження}

In this study is performed a review of literature. Review of literature is made with the data obtained from the studies in this field. In this context, it is aimed to reach a unique results.

\section{Results \\ Результати}

\section{What is psycholinguistics?}

Psycholinguistics or psychology of language is the study of the interrelation between linguistic factors and psychological aspects. Psycholinguistics is a science formed with the contributions of linguistics examining the origins, generations and the qualities of language usage, and of psychological science studying the human behaviours. Language acquisition focuses on its comprehension and usage (Özbay \& Barutçu, 2013: 987). According to Altman (2001) psycholinguistics that means psychology of language is the study of the psychological and neurological factors that enable humans to acquire, use, comprehend and produce language. Chomsky's views that discuss language development within biological and psychological context are referred to as "psycholinguistic" theories.

\section{Who is psycholinguist?}

A psycholinguist is a social scientist who studies psycholinguistics, which connects psychology and linguistics. Psycholinguistics is interdisciplinary in nature and is studied by people in a variety of fields, such as, psychology, cognitive science, linguistics, neuroscience and many more (Jodai, 2011: 2). 


\section{What is the aim of psycholinguistics?}

The main aim of psycholinguistics is to outline and describe the process of producing and comprehending communication. In psycholinguistics researchers try to develop models to describe and predict specific linguistic behavior (Jodai, 2011: 2). Psychological processes coming out during the language learning and its usage are analysed in the light of psycholinguistics (Özbay \& Barutçu, 2013: 987).

\section{What is the main interest of psycholinguistics?}

Psycholinguistics focuses on "how different kinds of motives affect how people talk or, more broadly, how they convey information in language" (Bock, Konopka \& Middleton, 2006: 1). The main subject of research in psycholinguistics is the study of cognitive processes that underlie the comprehension and production of language, and the way the cultural environment interact with these two (Harely, 2005). Psycholinguistics concerns with the study of the cognitive process that supports the acquisition and use of language. Psycholinguistics is the branch of cognitive psychology that studies the psychological basis of linguistic competence and performance. Psycholinguistics is concerned with the cognitive faculties and processes that are necessary to produce the grammatical constructions of language (Tatlılığlu \& Senchylo-Tatlılığlu, 2020: 245). Psycholinguistics is interdisciplinary and is studied in different fields such as psychology, cognitive science and linguistics. The main subject of research in psycholinguistics is the study of cognitive processes that underlie the comprehension and production of language, and the way the cultural environment interact with these two (Harely, 2005: 13).

\section{Stages of Language Development at the early childhood}

Early childhood is a child in the age of 0-6 years. At the age of 0-2 years of physical and brain growth is. The relationships they form and the experiences they have during their first five years of life have a huge impact on their brain's growth. The crucial years of development start from the moment they're born, to five years old. This period is filled with sensitive milestones that are key to their cognitive development.

In general, young children tend to follow a similar progression through of language development. There is no set timeline for this happening. Language development of children is divided in three periods, as follows:

Prelingual Period (age 0-1 years): At this period children cannot pronounce 'spoken language' as spoken of adults, in the sense of not following the rules of the applicable language. In this period the child has a language of its own, such as babbling instead of communication with others.
a. Newborn period (crying / 0-2 months)
b. Coughing / crying period (2-2 months)
c. Humming period (4-6 months) 
d. Repetitive humming period (7-9 months)

e. Imitation of others voices period (9-11 months).

Early Lingual Period (1 to 3 years): In this period, children began to speak the first words, though not yet complete. There are 4 stages:

a. Sound, word period (9-12 months): During this period, the baby often murmurs, forming long sequences resembling adult speech, and making fluent sounds that are incomprehensible, similar to straight sentences or interrogative sentences.

b. One-word stage (12-18 months): Also known as the holophrastic stage, this typically occurs when a child is between nine-months-old and 18-months-old, and involves communicating via single words, or a single word stem (i.e. doggy, no, stop, etc).

c. Two-word stage (18-24 months): Generally, the second sentence appears when children begin to understand a theme and try to express it. This one is exactly what it sounds like: when your little one speaks in basic two-word sentences. It typically occurs in toddlers between the ages of 18 and 24 months (i.e. doggy bark, mommy hat, etc).

d. Early multiword stage (2-3 age months): The period of sentence of more than two words shows the ability of children in the field of morphology. Skills form the sentence increased. Also known as the telegraphic stage, this is when children are asked to repeat sentences, and when they do, leave out a few words (i.e. "I can see a cow" repeated as "See cow"). Toddlers typically reach this stage between 24 and 30 months.

Differentiation Period (3-6 years): During this period, the child begins to speak in accordance with grammatical rules. In this period children's skills in organizing the differentiation of words and sentences are more appropriate. Broadly, the general characteristics of language development in this period are as follows:

$\checkmark$ Phonological development may be said to have ended. There may still be difficulty in pronouncing pluralistic and complex consonants.

$\checkmark$ Vocabulary gradually began to grow. Nouns and verbs are more differentiated in its use, it is characterized by the use of prepositions, pronouns and auxiliary verbs.

$\checkmark$ Language for communication functions properly - really starts to work. Children want to share their perception and experience of the outside World to other people, by providing feedback, ask, order, tell and others.

$\checkmark$ Start the development of morphology, characterized by the emergence of a plural word, change the suffix, change verbs, and others (Indrayani, 2016: 281-283; Duran \& Kenanoğlu, 2020: 16-18; Chomsky, 2011). 


\section{Conclusions}

Висновки

The result shows that there are several theories have challenged the development of language, such theories are natavism, cognitivism, and behaviourism. Language development is divided into three periods, namely: Period Prelingual, Early Lingual Period and Differentiation Period. Start early period this early lingual child starts to say the word first word which is the most amazing moment for parents. The factors that affect languages development including health, intelligence, social economic condition, family relationship, family size, peer relationships and personality (Indrayani, 2016). It is seen that studies on language development have increased in recent years. Since psycholinguistics is a broad area, there are many studies which were done from different aspects of psycholinguistics.

Language development is always in line with the growth of the child. Parents should always pay attention to these development, because at this time, largely determines the learning process. This can be done by giving a good example, to motivate children to learn. Parents are largely responsible for the success of children's learning and should always strive to improve the potential of children in order to develop optimally (Indrayani, 2016: 279).

Many studies have been carried out in the country and abroad on psycholinguistics. According to the findings of the research conducted by Duran \& Kenanoğlu (2020: 15) due to the fact that psycholinguistics is an interdisciplinary field, nowadays it is the focus of researchers who study the interrelation between mind and language. It was determined that education based on multiple intelligence theory, game-based education program, education technologies and material supported education, High Scope program and DMOEP contributed positively to children's language development (Duran \& Kenanoğlu, 2020: 15).

\section{References \\ Лimepamypa}

Altman, T.M.G. (2001). Psycholinguistics in review. British Journal of Psychology, 92, 129-170. https://doi.org/10.1348/000712601162130

Ateş, M. (2019). Psycholinguistic development and Content and Language Integrated Learning (Clil) Across Early Chilhood. (Unpublished Master Thesis) İstanbul Sebahattin Zaim University, Institute of Social Sciences.

Bock, K., Konopka, A., \& Middleton, E. (2006). Spoken Language Production: Psycholinguistic Approach. Encyclopedia of Language \& Linguistics, 103-112. https://doi.org/10.1016/b008-044854-2/00799-9

Chomsky, N. (2011). Dil ve Zihin. (Translater:Ahmet Kocaman). Ankara: Bilgesu Publications. 
Çelik, İ. (2017). Noam Chomsky and Psycholinguistics Theory. International Periodical for the Languages, Literature and History of Turkish or Turkic, 12(28), 193-208. https://doi.org/10.7827/TurkishStudies.12507

Duran, M. \& Kenanoğlu, D. (2020). Content Analysis of Studies on Language Development in Early Childhood. Journal of Inonu University Health Services Vocational School, 8(1), 1535.

Harely, T. (2005). The Psychology of Language. From Data to Theory, New, 52, 13-21.

Indrayani, N. (2016). Language Development at Early Childhood. International Conference on Education (IECO) Proceeding, 1(1), 279-289.

Jodai, H. (2011). An Introduction to Psycholinguistics. The University of Guilan, Iran.

Özbay, M. \& Barutçu, T. (2013). Psycholinguistics and Turkish teaching, Adıyaman University. Journal of Social Sciences, 6(11), 933-973. https://doi.org/10.14520/adyusbd.457

Tatlılığlu, K., \& Senchylo-Tatlılığlu, N. (2020). A Theoretical Perspective on Psycholinguistics. Psycholinguistics in a Modern World - 2020. Proceedings of the 15th International Scientific and Practical Conference (pp. 241-245). (Pereiaslav-Khmelnytskyi, 22-23 October 2020). https://doi.org/10.31470/10.31470/2706-7904-2020-15-241-245

Taştekin, A. (2016). Areas of interest in psycholinguistics, International Periodical for the Languages, Literature and History of Turkish or Turkic 11(4), 987-1000. https://doi.org/10.7827/TurkishStudies.9075

\section{Online Links:}

https://en.wikipedia.org/wiki/Psycholinguistics, Accessed: 10.11.2021.

https://files.eric.ed.gov/fulltext/ED521774.pdf, Accessed: 10.11.2021.

https://www.scarymommy.com/stages-language-development, Accessed: 11.11.2021. 